\title{
Fetal stimulation of maternal immunoglobulin production in mice*
}

\author{
J. Carter† and D. W. Dresser \\ National Institute for Medical Research, Mill Hill, London NW7 IAA, U.K.
}

\begin{abstract}
Summary. Within 12-24 h of parturition in mice, there was a dramatic increase in the number of immunoglobulin secreting cells in the paraaortic lymph nodes (PALN) draining the pregnant uterus. Compared with stimulation with lipopolysaccharide the ratio of $\mathrm{IgG}: \mathrm{IgM}$ forming cells was very high in PALN draining a pregnant uterus. The response was eliminated when fetectomy (ablating the embryo but leaving the placenta intact) was carried out on the 12th day of pregnancy. With unilateral fetectomy the uterine horn with intact fetal/placental units can be used as a positive control since lymphoid drainage is laterally confined. Neither healthy (gross and histological criteria) nor partly necrotic placentae stimulated Ig secreting cells in the PALN. The placentae of bilaterally fetectomized females were delivered apparently normally and at about the same time as normal (control) fetuses.

Injection of prostaglandin E-2 or F-2 $\alpha$ into the tail base led to the appearance of Igforming cells in the PALN of normal (virgin) female mice. Indomethacin fed to the pregnant female greatly reduced the numbers of these cells in the PALN. We conclude that the observed local stimulation of maternal Ig production by the fetus may be involved in the transplacental transfer of $\mathrm{Ig}$ from mother to fetus.
\end{abstract}

\section{Introduction}

Just before parturition, the maternal immune system is stimulated to produce significant numbers of immunoglobulin-forming cells in the paraaortic lymph nodes (PALN) which drain the uterus. The stimulation is similar to that produced by random (polyclonal) activators such as lipopolysaccharide but differs in that the ratio of $\operatorname{IgG}: \operatorname{IgM}$ secreting cells is unusually high (Carter \& Dresser, 1983). The increase in the number of IgG-forming cells is positively correlated with an increase in the number of $B$ cells seen in the PALN during the last week of pregnancy in the mouse. The effect, which is confined to the PALN and is not seen in other lymph nodes, is not affected by allogenicity, multiparity or sex of the fetus (Carter, Newport, Keeler \& Dresser, 1983; Newport \& Carter, 1983). The observed effect is consistent with changes in maternal lymphoid organs, including an increase in the size of the spleen and PALN, described previously by Maroni \& de Souza (1973), Ansell, McDougall, Speedy \& Inchley (1978) and Chatterjee-Hasrouni, Santer \& Lala (1980).

If, as appears likely at first sight, the increase is non-specifically induced by a random (polyclonal) activator of immunoglobulin production, it is of some relevance to determine the nature of the trigger substance(s) and its (their) relationship to the mechanism of parturition. In the present study we have investigated (1) whether the source of the stimulatory substance(s) or factor(s) is the fetus and or the placenta and (2) the role of prostaglandins.

\footnotetext{
* Reprint requests to Dr D. W. Dresser.

† Present address: Nuffield Department of Obstetrics \& Gynaecology, John Radcliffe Hospital, Oxford OX3 9DU, U.K.
} 


\section{Materials and Methods}

Animals. The CBA/Ca NIMR female mice, 9-12 weeks of age, were bred and mated (with CBA/Ca NIMR males, except as specifically indicated otherwise) in specific pathogen-free conditions. The day of finding a vaginal plug was called Day 1 of pregnancy. Mice were removed to a category 1 (minimal disease) unit on Day 12 of pregnancy. Cell suspensions from lymph nodes were made within $1 \mathrm{~h}$ of collection of the mice from the category 1 unit.

Cell preparations. Cell suspensions were made by disrupting lymph nodes in Hank's balanced salt solution containing $0.5 \%$ (w/v) gelatin (Difco, East Molesey, Kent, U.K.) (Medium HG), using a loose fitting polytetrafluorethylene (Teflon) homogenizer. The suspension at $22^{\circ} \mathrm{C}$ was then pipetted through a stainless-steel sieve $(30 \mathrm{mesh} / \mathrm{cm})$ before being centrifuged at $250-300 \mathrm{~g}$ for 5 min at $4^{\circ} \mathrm{C}$. The cells, now at $4^{\circ} \mathrm{C}$, were resuspended in cold Medium HG and then stored on ice ready for use in the plaque assay.

Plaque assay. The haemolytic plaque assays, essentially a modification of the original method of Jerne, have been described in detail elsewhere (Dresser, 1978). The reversed plaque assay for cells secreting IgM and IgG was based on the method of Molinaro \& Dray (1974). The target cells for this assay were prepared using freshly dissolved chromic chloride in a slightly modified procedure of the method previously described (Dresser \& Popham, 1980). Sheep erythrocytes washed in saline $(0 \cdot 15 \mathrm{M}-\mathrm{NaCl}$; at this stage in this procedure it is essential that there is a complete absence of phosphate ions) were made up to a $50 \%(\mathrm{v} / \mathrm{v})$ suspension in saline and one volume of this suspension was added to 10 volumes of a $2 \mathrm{mg} / \mathrm{ml}$ solution of goat $\mathrm{IgG}$ in saline at $22^{\circ} \mathrm{C}$. Ten volumes of a freshly prepared solution of $\mathrm{CrCl}_{3}(10 \mathrm{mg}$ in $100 \mathrm{ml} 0.15 \mathrm{M}-\mathrm{NaCl})$ at $22^{\circ} \mathrm{C}$ were then 'instantly' mixed with the sheep $\mathrm{RBC} /$ protein mixture by rapidly pipetting in the chromic chloride solution, while the former was vigorously agitated on a vortex mixer. After incubation for $10-20 \mathrm{~min}$ at $22^{\circ} \mathrm{C}$, the reaction was stopped by the addition of a physiological buffer containing phosphate ions. The sheep RBCs were washed several times in Medium $\mathrm{HG}$, and stored in Medium $\mathrm{HG}$ at $0-2^{\circ} \mathrm{C}$ for up to 4 days.

The goat IgG used to prepare target cells for the reversed plaque assay was prepared by ionexchange chromatography on DEAE-cellulose (DE52 Whatman; fraction eluted by 0.01 M-Tris$\mathrm{HCl} \mathrm{pH} 8 \cdot 1,0.02 \mathrm{M}-\mathrm{NaCl}$ ) from the serum of hyperimmune goats. One serum (GO-9) was highly specific for the $\mu$-chain of mouse $\operatorname{Ig}($ mouse $\mu)$ and the other $(\mathrm{GO}-4)$ had strong activity against the $\gamma$-chain of mouse Ig (mouse $\gamma$ ) and significant activity against the Fab fragment of mouse Ig. In all reversed plaque assays, developing sera were used: specific anti-mouse $\mu$ (raised in a rabbit) was added to detect IgM producers and a combination of a rabbit serum with specificity for mouse $\gamma-1$, and mouse $\gamma-2$ and an inhibitory goat (IgGl) anti-mouse $\mu$ when the assay was intended to detect IgG-producing cells. The few direct IgM plaques were inhibited because their presence could lead to significant inaccuracies in the estimation of relatively low number of IgG-forming cells. In the assay for IgM antibody-forming cells to sheep RBCs, no developing sera were added since these IgM plaque-forming cells show up as direct plaques. In the estimation of IgG (anti-sheep RBC) plaque-forming cells, as in the procedure used in the reversed assay for IgG secretors, the appearance of $\operatorname{IgM}$ plaques was inhibited by the addition of a goat anti-mouse $\mu$ serum.

Fetectomy. The method of Newton (1935) was used. Mice were anaesthetized with ether on Day 12 of pregnancy and the abdomen palpated to locate the developing embryos. The amniotic sac of each fetus was burst by digital pressure. Fetectomy was either uni- or bi-lateral. After the former the ipsilateral and contralateral PALN which separately drain the two horns of the uterus were assayed separately for IgM- and IgG-forming cells on the 19th or 20th day of pregnancy.

Hormone injections. Mice treated with progesterone were injected subcutaneously (s.c.) in the subscapular region with $1 \mathrm{mg}$ of a long-acting progestagen (Depo-Provera: Upjohn, Crawley, Sussex, U.K.) or with progesterone (Sigma, Poole, Dorset, U.K.) dissolved in arachis oil, usually 7- 
10 days before injection of prostaglandins (PG). Stock solutions of PGs were prepared as follows; PGE-2 (Sigma) was dissolved $(2 \mathrm{mg} / \mathrm{ml})$ in absolute ethanol and stored at $-70^{\circ} \mathrm{C}$ in a nitrogen atmosphere; PGF- $2 \alpha$ was dissolved $(2 \mathrm{mg} / \mathrm{ml})$ in an aqueous buffer at $\mathrm{pH} 8$ and stored at $0-2^{\circ} \mathrm{C}$. PGs were diluted in phosphate buffer immediately before injection (s.c.) into the tail base of mice. The timing/frequency of hormone injections are indicated in the 'Results'.

In other experiments involving injected steroid hormones, the steroids were dissolved in arachis oil and injected (s.c.) in the tail base: the hormones used were cortisone and cortisone acetate (5$500 \mu \mathrm{g})$, hydrocortisone and hydrocortisone acetate $(5-500 \mu \mathrm{g})$, oestradiol-17 $(0 \cdot 1 \mu \mathrm{g}$ : Sigma), dexamethasone $(200 \mu \mathrm{g})$ and aldosterone $(200 \mu \mathrm{g})$. Oestradiol-17 $\beta$ was also administered in conjunction with, and with regard to timing between, progesterone and PGE- 2 or PGF- $2 \alpha$, but had no measurable effect, neither increasing nor decreasing the number of Ig-forming cells induced by the progesterone/PG treatment.

Statistical analysis. Results are expressed as the arithmetic mean of cells per lymph node and of Ig-forming cells per $10^{6}$ PALN cells with one standard error of the mean (s.e.) for each group of experimental mice. Student's $t$ test was used to estimate $P$ values (one-tailed test) between control and experimental groups.

Histology. Uteri were fixed in two changes of neutral buffered formalin for a minimum of $24 \mathrm{~h}$. Longitudinal sections were made of individual horns. Sections were stained with haematoxylin and eosin by a standard procedure.

\section{Results}

\section{The effect of fetectomy on the timing of parturition}

Fetectomy did not affect the time of parturition in syngeneically $(\mathrm{CBA} \times \mathrm{CBA})$ pregnant mice. In an experiment in which 12-day-pregnant mice were bilaterally fetectomized and compared with age-matched normally pregnant controls, there was no difference in the time of delivery of the placentae ( 3 at Day 20, 3 at Day 21 and 1 at Day 22) and of the normal fetuses ( 3 at Day 20 and 4 at Day 21).

Histology of sections of uteri from fetectomized females on Day 19 of pregnancy showed that the placentae were viable and there was no evidence of necrosis. In uteri from bilaterally fetectomized females 1 day after parturition the placentae were no longer present. In a small number of mice the placentae were necrotic and being resorbed on Days 17-20 of 'pregnancy', probably due to too much pressure at fetectomy.

\section{The effect of fetectomy on immunoglobulin secretion}

The ipsilateral and contralateral PALN from unilaterally fetectomized mice were examined for IgG- and IgM-forming cells (Table 1). There was no immunoglobulin secretion, above that seen in virgin controls, in the PALN that drained the uterine horn bearing placentae. The expected high increase in IgG-and IgM-secreting cells was found in the PALN draining the horn bearing normal embryos. There was no difference in this result when in an early experiment too much pressure was exerted at fetectomy and the placentae were necrotic and being resorbed. This pattern of results, in terms of gross cell number in the various lymph nodes, was similar to that described above for Igforming cells.

\section{The effect of hormones on immunoglobulin secretion}

Steroid hormones (listed in 'Materials and Methods'), when injected into the tail base of 12week-old virgin CBA females, had no incremental effect on immunoglobulin synthesis in the 
Table 1. The effect of fetectomy on the 12th day of pregnancy on the number of Ig-forming cells in the para-aortic lymph nodes (PALN) of mice on the 19th or 20th day of "pregnancy"

\begin{tabular}{|c|c|c|c|c|c|}
\hline \multirow[b]{2}{*}{ Exp. } & \multirow[b]{2}{*}{ Treatment } & \multirow{2}{*}{$\begin{array}{l}\text { Horn of } \\
\text { uterus }\end{array}$} & \multirow{2}{*}{$\begin{array}{c}\text { Mean (s.e.m.) } \\
\text { no. of cells } \\
\text { per single PALN } \\
\left(\times 10^{-6}\right)\end{array}$} & \multicolumn{2}{|c|}{$\begin{array}{l}\text { Mean (s.e.m.) no. of } \\
\text { Ig-forming cells } / 10^{6} \text { PALN cells }\end{array}$} \\
\hline & & & & $\operatorname{Ig} M$ & $\lg G$ \\
\hline \multirow[t]{3}{*}{1} & None (virgin controls) & Both & $\begin{array}{c}0 \cdot 89 \\
(0 \cdot 16)\end{array}$ & $\begin{array}{l}6 \\
(2)\end{array}$ & $\begin{array}{c}5 \\
(3)\end{array}$ \\
\hline & $\begin{array}{l}\text { Fetectomized } \\
\text { (placentae not viable) }\end{array}$ & Left & $\begin{array}{c}1.01 \\
(0 \cdot 13)\end{array}$ & $\begin{array}{c}9 \\
(4)\end{array}$ & $\begin{array}{c}6 \\
(4)\end{array}$ \\
\hline & None & Right & $\begin{array}{c}4.06 \\
(0.82)\end{array}$ & $\begin{array}{c}71 \\
(20)\end{array}$ & $\begin{array}{l}1145 \\
(449)\end{array}$ \\
\hline \multirow[t]{2}{*}{2} & $\begin{array}{l}\text { Fetectomized } \\
\text { (placentae viable and healthy) }\end{array}$ & Left & $\begin{array}{c}0 \cdot 52 \\
(0 \cdot 12)\end{array}$ & $\begin{array}{c}62 \\
(18)\end{array}$ & $\begin{array}{c}59 \\
(31)\end{array}$ \\
\hline & None & Right & $\begin{array}{l}1 \cdot 65 \\
(0 \cdot 26)\end{array}$ & $\begin{array}{l}226 \\
(80)\end{array}$ & $\begin{array}{c}3096 \\
(1554)\end{array}$ \\
\hline
\end{tabular}

Five animals per group and 3 or more fetuses in each uterine horn.

Since Exps 3 and 4 were identical in design and gave results similar to those of Exp. 2, the details of these experiments are not included.

Table 2. The effect of the numbers of Ig-forming cells in the PALN of prostaglandins injected into the tail base of mice treated with progesterone

\begin{tabular}{|c|c|c|c|c|c|}
\hline \multicolumn{2}{|c|}{ Treatment (day of pregnancy) } & \multirow{2}{*}{$\begin{array}{c}\text { No. of } \\
\text { mice }\end{array}$} & \multirow{2}{*}{$\begin{array}{l}\text { Mean (s.e.m.) } \\
\text { no. of cells } \\
\text { per single PALN } \\
\quad\left(\times 10^{-6}\right)\end{array}$} & \multicolumn{2}{|c|}{$\begin{array}{c}\text { Mean (s.e.m.) no of } \\
\text { Ig-forming cells } / 10^{6} \text { PALN cells }\end{array}$} \\
\hline Progesteronet & Prostaglandin $\ddagger$ & & & IgM & IgG \\
\hline Arachis oil $(12,13)$ & Saline $(12,13,14)$ & 3 & $0.83(0.35)$ & $50(18)$ & $12(8)$ \\
\hline $1 \mathrm{mg}(12,13)$ & Saline $(12,13,14)$ & 4 & $0.73(0.02)$ & $28(18)$ & $11(6)$ \\
\hline Arachis oil $(12,13)$ & $\begin{array}{l}\text { E-1 }(12,13,14) \\
\text { E-2 }(12,13,14) \\
\text { F-2 } \alpha(12,13,14)\end{array}$ & $\begin{array}{l}4 \\
5 \\
4\end{array}$ & $\begin{array}{l}2.09(0.28) \\
0.98(0.20) \\
1.96(0.29)\end{array}$ & $\begin{array}{r}98(61) \\
* 420(85) \\
* 617(79)\end{array}$ & $\begin{array}{l}198(193) \\
830(549) \\
774(220)\end{array}$ \\
\hline $1 \mathrm{mg}(12,13)$ & $\begin{array}{l}\text { E-1 }(12,13,14) \\
\text { E-2 }(12,13,14) \\
F-2 \alpha(12,13,14)\end{array}$ & $\begin{array}{l}3 \\
4 \\
4\end{array}$ & $\begin{array}{l}0.99(0.10) \\
1.27(0.30) \\
2.69(0.56)\end{array}$ & $\begin{array}{c}29(16) \\
* * 439(153) \\
* * 560(110)\end{array}$ & $\begin{array}{c}11(8) \\
* * 1381(132) \\
* 550(194)\end{array}$ \\
\hline
\end{tabular}

$\uparrow$ Progesterone dissolved in $50 \mu 1$ arachis oil.

$\ddagger$ Prostaglandins $(5 \mu \mathrm{g})$ dissolved in $25 \mu \mathrm{l}$ saline immediately before injection in the tail base.

${ }^{*} P<0.02,{ }^{* *} P<0.01$ compared with equivalent saline controls.

PALN which drains that area, and at higher doses usually had a marked suppressive effect on the numbers of background (spontaneous) Ig-forming cells. Prostaglandins E- 2 and F- $2 \alpha$ increased the numbers of IgG- and IgM-forming cells in the PALN after injection into the tail base. Although progesterone alone did not positively affect secretion there seemed to be a synergistic effect between progesterone and PG when the progesterone was given at the same time as the PG (Table 2), or sometime before the PG (Table 3). Several experiments failed to demonstrate any positive effects resulting from the injection of oestrogen, and the results in Table 4 demonstrate that oestrogen neither abolishes nor increases the combined effect of progesterone and PG.

The stimulatory effect of an embryo, removed by fetectomy at Day 12 of pregnancy, could be mimicked by the injection of PGE-2 or PGF-2 $\alpha 3$ and 4 days before the plaque assay of the PALN (Table 4). 
Table 3. The effect of combined treatment with progesterone, oestrogen and prostaglandin on the number of Ig-forming cells in the PALN of mice

\begin{tabular}{|c|c|c|c|c|}
\hline \multirow[b]{2}{*}{ Treatment (days before plaque assay) } & \multirow{2}{*}{$\begin{array}{l}\text { No. of } \\
\text { mice }\end{array}$} & \multirow{2}{*}{$\begin{array}{l}\text { Mean (s.e.m.) } \\
\text { no. of cells } \\
\text { per single PALN } \\
\left(\times 10^{-6}\right)\end{array}$} & \multicolumn{2}{|c|}{$\begin{array}{c}\text { Mean (s.e.m.) no. of } \\
\text { Ig-forming cells } / 10^{6} \text { PALN cells }\end{array}$} \\
\hline & & & IgM & IgG \\
\hline $\begin{array}{l}\text { Controls } \\
\text { (saline in tail base) }(3,2,1)\end{array}$ & 4 & $0.68(0 \cdot 10)$ & $46(23)$ & $30(16)$ \\
\hline $\begin{array}{l}\text { Progestagen }(1 \mathrm{mg}) \text {, s.c. }(14) \\
\text { Oestrogen }(25 \mathrm{ng}) \text {, tail base }(6,4) \\
\text { PGE-2 }(5,4,3)\end{array}$ & 5 & $0.78(0.08)$ & $521(240)$ & $1167(683)$ \\
\hline $\begin{array}{l}\text { Progestagen }(1 \mathrm{mg}), \text { s.c. }(14) \\
\text { Oestrogen }(25 \mathrm{ng}) \text {, tail base }(4,2) \\
\text { PGE-2 }(3,2,1)\end{array}$ & 5 & $0.72(0.11)$ & $269(212)$ & $226(160)$ \\
\hline
\end{tabular}

Table 4. Prostaglandin can restore the IgG "response" in the PALN of fetectomized pregnant mice

\begin{tabular}{lcccc}
\hline & $\begin{array}{c}\text { Mean (s.e.m.) } \\
\text { no. of cells } \\
\text { Treatment (days of 'pregnancy') }\end{array}$ & $\begin{array}{c}\text { No. of } \\
\text { mice }\end{array}$ & $\begin{array}{c}\text { per single PALN } \\
\left(\times 10^{-6}\right)\end{array}$ & $\begin{array}{c}\text { Mean (s.e.m.) no. of } \\
\text { Ig-forming cells/106 PALN cells } \dagger\end{array}$ \\
\cline { 5 - 6 } Control $(25 \mu$ l saline in tail base) $(15,16)$ & 6 & $0.68(0.22)$ & $62(16)$ & $18(6)$ \\
Normal pregnancy & 5 & 0.56 & $* * 223(64)$ & $* * 660(277)$ \\
\hline Fetectomized (12); saline control $(15,16)$ & 4 & $0.86(0 \cdot 18)$ & $107(14)$ & $17(9)$ \\
Fetectomized (12); PGF-2 $\alpha(15,16)$ & 5 & 0.98 & $129(40)$ & $* 486(204)$ \\
Fetectomized (12); PGE-2 $(15,16)$ & 7 & $1.06(0.18)$ & $142(22)$ & $142(70)$ \\
\hline
\end{tabular}

${ }^{*} P<0.05 ;{ }^{* *} P<0.02$ compared with respective saline control.

$\dagger$ Plaque assay on 19th day of pregnancy.

Table 5. The timing of parturition after indomethacin fed ad libitum to pregnant $(\mathrm{CBA} / \mathrm{Ca} \times \mathrm{CBA} / \mathrm{Ca})$ mice

\begin{tabular}{|c|c|c|c|c|}
\hline \multirow{2}{*}{$\begin{array}{l}\text { Start of indomethacin treatment } \\
\text { (day of pregnancy) }\end{array}$} & \multicolumn{2}{|c|}{ Indomethacin } & \multicolumn{2}{|c|}{ Controls } \\
\hline & No. of mice & Day of parturition & No. of mice & Day of parturition \\
\hline 13 & 5 & 21 & 4 & 20 \\
\hline & 1 & 22 & 2 & 21 \\
\hline 14 & 1 & 20 & 1 & 20 \\
\hline 15 & 1 & 20 & 3 & 20 \\
\hline & 4 & 21 & 2 & 21 \\
\hline
\end{tabular}

The effect of indomethacin on parturition and immunoglobulin secretion

Indomethacin at a concentration of $25 \mathrm{mg} / 1$ drinking water fed ad libitum to pregnant mice from Day 13, 14 or 15 of pregnancy until parturition did not affect the timing of birth (Table 5). Twelve control and 11 indomethacin-fed mice gave birth on Days 20 and 21 and 1 indomethacin-fed animal on Day 22.

Indomethacin fed ad libitum to mice from Day 15 of pregnancy before assay on Day 20 reduced the number of Ig-forming cells in the PALN. In two experiments (Table 6) the expected increase in immunoglobulin synthesis on Day 20 of pregnancy was inhibited $(P<0.05)$. 
Table 6. The effect of feeding indomethacin to pregnant mice

\begin{tabular}{|c|c|c|c|c|c|c|}
\hline \multirow[b]{2}{*}{ Exp. } & \multirow[b]{2}{*}{ Treatment } & \multirow[b]{2}{*}{ Indomethacin $\dagger$} & \multirow{2}{*}{$\begin{array}{l}\text { No. of } \\
\text { mice }\end{array}$} & \multirow{2}{*}{$\begin{array}{l}\text { Mean (s.e.m.) } \\
\text { no. of cells } \\
\text { per single PALN } \\
\left(\times 10^{-6}\right)\end{array}$} & \multicolumn{2}{|c|}{$\begin{array}{l}\text { Mean (s.e.m.) no. of } \\
\text { Ig-forming cells } / 10^{6} \text { PALN cells }\end{array}$} \\
\hline & & & & & $\operatorname{IgM}$ & IgG \\
\hline \multirow[t]{3}{*}{ i } & Virgin controls & - & 5 & $0.66(0.23)$ & $4(3)$ & $4(3)$ \\
\hline & Pregnant & - & 6 & $1.07(0.19)$ & $146(65)$ & 5637 (2038) \\
\hline & & + & 6 & $0.93(0.20)$ & $65(26)$ & *1607 (841) \\
\hline \multirow[t]{2}{*}{2} & Pregnant & - & 4 & $1.98(0.48)$ & $230(96)$ & $1488(593)$ \\
\hline & & + & 4 & $1.15(0.07)$ & *40(11) & $181(131)$ \\
\hline
\end{tabular}

$\dagger$ Indomethacin $(25 \mathrm{mg} / \mathrm{l})$ fed ad libitum from 15 th day of pregnancy. Plaque assay on 20 th day of pregnancy.

${ }^{*} P<0.05$ compared with respective pregnant mice not fed indomethacin.

\section{Discussion}

Previous experiments have shown that $\mathrm{T}$ - and $\mathrm{B}$-cells increase in number in the paraaortic lymph nodes (PALN) draining the pregnant uterus of the mouse (Carter et al., 1983; Newport \& Carter, 1983). The increase in cellularity was subsequently shown to be accompanied by a relatively greater increase in the number of cells secreting immunoglobulin $\mathrm{G}$ and to a lesser extent in those secreting IgM, in the same nodes (Carter \& Dresser, 1983). Surprisingly, in comparison with the random (polyclonal) mitogenic effect of bacterial lipopolysaccharide, pregnancy induced relatively more IgG- than IgM-forming cells (Carter \& Dresser, 1983). The stimulatory effect observed, unlike that of a classical antigen, is completely random, turning on immunoglobulin production with no relationship to antibody specificity. The effect of pregnancy is confined to the local lymph nodes draining the uterus (PALN), with no effect showing in the inguinal, popliteal or brachial lymph nodes.

The present experiments show that the source of the stimulus of Ig production in the PALN is likely to be the embryo and is unlikely to originate from the placenta. In unilateral pregnancies, the PALN draining the pregnant horn, but not that on the contralateral side (no fetus), was stimulated to produce Ig-forming cells: it is clear from this and experiments with injected dyes that the lymphoid drainage into the PALN is laterally restricted (Head \& Lande, 1983). It was therefore practicable to fetectomize one horn leaving intact feto-placental units in the contralateral horn as a control. The method of fetectomy (Newton, 1935) requires a degree of manual skill and until this is achieved it is easy to use too much pressure which results not only in fetectomy but also in damage to the placentae, which become necrotic and are usually in the process of resorption at the time of the plaque assay (Day 19 or 20 of pregnancy). However, despite the presence of degenerate placentae in some of the early experiments, there was no activation of Ig synthesis in the local PALN (Table 1). Placentae were only classified as being 'healthy' if there was no evidence of necrosis at histological examination.

Although it is clear that an intact embryo must be present for stimulation of Ig-forming cells, it is not clear whether the embryo is involved in triggering parturition since we cannot rule out the possibility that fetal membranes are retained with the placentae after fetectomy. It is not impossible that such embryonic membranes may be a source of the signal triggering parturition.

Purely on a-priori grounds, it seemed possible that the triggering factor could be a hormone. We therefore measured the effect of various hormone preparations in stimulating Ig-forming cells after injection into the tail base of normal, non-pregnant female mice : the tail base drains into the PALN as well as into the inguinal lymph nodes. None of the steroids tried (including various gluco- and mineralo-corticoids) had any stimulatory effect on Ig-forming cells in the PALN when injected on their own: however, a synergistic effect was seen when treatment with progesterone was combined 
with the injection of prostaglandins (PG) into the same region (Tables 2 \& 3). On their own PGE-2 and PGF- $2 \alpha$ had a marked stimulatory effect in about half the mice in each experimental group: this was reflected in the very large variance (s.e.). Groups of animals pretreated or concomitantly treated with progesterone seemed to show a more consistent response to injected PGs. However, the suppressive effect of fetectomy in reducing the number of Ig-forming cells in the PALN was reversed if PGE-2 or PGF-2 $\alpha$ were injected into the tail base (Table 4). This result strengthens the view that prostaglandins play an important role in the signal delivered by the embryo to the mother, one aspect of which is the stimulation of Ig production in the local maternal lymph node. An early report on the adjuvant-like properties of various prostaglandins provides a further indication of their ability to stimulate synthesis of Ig in vivo (Ishizuka, Takeuchi \& Umezawa, 1974). Other aspects may be involved in the triggering of parturition, although this is far from being made clear in the current experiments. It is not impossible that the great variability of the results obtained in experiments using prostaglandins is due to the instability and rapid metabolism of these hormones (Poyser, 1981).

If prostaglandins are involved in fetus-to-mother signalling, then drugs that inhibit PG synthesis should also inhibit Ig-forming cells in the PALN during late pregnancy. Indomethacin seemed suitable (Embrey, 1983) and this was fed ad libitum to the experimental mice at a dose of 25 $\mathrm{mg} / \mathrm{l}$ drinking water. This concentration was chosen as the highest dose which did not cause any detectable side-effects such as intraperitoneal haemorrhages or adhesions. It is clear from the results in Tables 5 and 6 that, while indomethacin had no marked effect in delaying parturition, it significantly suppressed the number of Ig-forming cells in the PALN of 20-day-pregnant mice. While these results can be interpreted as further support for the role of prostaglandins, it must be emphasized that indomethacin has many side-effects, other than blocking PG synthesis (Embrey, 1983), which may contribute to the observed suppression of IgG-forming cells in the PALN. The reported stimulation of a decidual cell reaction by PGF- $2 \alpha$ injected into hormonally prepared rats and the partial blocking of this stimulation by indomethacin (Miller \& O'Morchoe, 1982a, b) are both compatible with and analogous to our results.

The experiments described in this paper suggest that, in the mouse, the increase in immunoglobulin synthesis by maternal B-cells in the lymph nodes draining the pregnant uterus is controlled by the fetus. Since this Ig production is confined to the PALN and temporally restricted to the last few days of pregnancy, it seems possible that this is an efficient and economical mechanism for producing $\lg$ (IgG in particular) for transplacental transport to the developing fetus. There is some evidence which supports the view that it is mainly IgG that traverses the placenta and that the bulk of this transport normally takes place at the end and not throughout pregnancy (Brambell, 1970).

We thank A. M. Popham for invaluable assistance.

\section{References}

Ansell, J.D., McDougall, C.M., Speedy, G. \& Inchley, C.J. (1978) Changes in lymphocyte accumulation and proliferation in the lymph nodes draining the pregnant uterus. Clin. exp. Immunol. 31, 397-407.

Brambell, F.W.R. (1970) The transmission of passive immunity from mother to young. In Frontiers of Biology, Vol. 180. North Holland Publishing Co., Amsterdam.

Carter, J. \& Dresser, D.W. (1983) Pregnancy induces an increase in the number of immunoglobulin-secreting cells. Immunology 49, 481-490.

Carter, J., Newport, A., Keeler, K.D. \& Dresser, D.W. (1983) FACS analysis of changes in $T$ and $B$ lymphocyte populations in the blood, spleen and lymph nodes of pregnant mice. Immunology 48, 791797.

Chatterjee-Hasrouni, S., Santer, V. \& Lala, P.K. (1980) Characterization of maternal small lymphocyte subsets during allogeneic pregnancy in the mouse. Cell. Immunol. 50, 290-304.

Dresser, D.W. (1978) Assays for immunoglobulin secreting cells. In Handbook of Experimental Immunology, 3rd edn, pp. 28.1-28.25. Ed. D. M. Weir. Blackwell Scientific, Oxford.

Dresser, D.W. \& Popham, A.M. (1980) Rheumatoid factors in mice: plaque assay for homophile and 
heterophile rheumatoid factors. Immunology 41, 569577.

Embrey, M. (1983) Prostaglandins in human reproduction. In Oxford Reviews of Reproductive Biology, vol. 5, pp. 62-105. Ed. J. R. Clarke. Clarendon Press, Oxford.

Head, J.R. \& Lande, I.J.M. (1983) Passage of ink and lymphoid cells from the rat uterine wall and lumen. Biol. Reprod. 28, 941-955.

Ishizuka, M., Takeuchi, T. \& Umezawa, H. (1974) Promotion of antibody formation by prostaglandin. Experientia 30, 1207-8.

Maroni, E. \& de Souza, M.A.B. (1973) The lymphoid organs during pregnancy in the mouse. A comparison between a syngeneic and an allogeneic mating. Clin. exp. Immunol. 13, 107-124.

Miller, M.M. \& O'Morchoe, C.C.C. (1982a) Decidual cell reaction induced by prostaglandin $F_{2}$ in the mature cophorectomized rat. Cell Tiss Res. 225, 189-199.
Miller, M.M. \& O'Morchoe, C.C.C. (1982b) Inhibition of artificially induced decidual cell reaction by indomethacin in the mature oophorectomized rat. Anat. Rec. 204, 223-230.

Molinaro, G.A. \& Dray, S. (1974) Antibody coated erythrocytes as a manifold probe for antigen. Nature, Lond. 248, 515-517.

Newport, A. \& Carter, J. (1983) Changes in T and B lymphocyte populations in the lymph nodes draining the uterus in pregnant mice. J. Reprod. Fert. 67, 433440.

Newton, W.H. (1935) 'Pseudo-parturition' in the mouse and the relation of the placenta to post-partum oestrus. J. Physiol., Lond. 84, 196-207.

Poyser, N.L. (1981) Prostaglandins in reproduction. In Prostaglandins Research Studies Series, pp. 1-180. Ed. Y. S. Bakhle. John Wiley \& Sons Ltd, Chichester.

Received 28 September 1984 